\title{
Combining modelling, field data and genetic variation to understand the post-reintroduction population genetics of the Marsh Fritillary butterfly (Euphydryas aurinia)
}

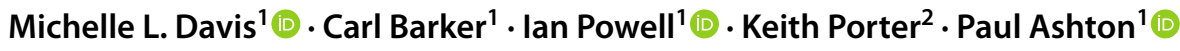

Received: 2 August 2021 / Accepted: 4 October 2021 / Published online: 10 October 2021

(c) The Author(s) 2021

\begin{abstract}
The Marsh Fritillary butterfly (Euphydryas aurinia) is a Eurasian species which has suffered significant reductions in occurrence and abundance over the past century, particularly across the western side of its range, due to agricultural intensification and habitat loss. This loss has been particularly severe in the UK with extensive localised extinctions. Following sympathetic management, reintroduction was undertaken at four Cumbria (northern UK) sites in 2007 with stock from a captive admixture population descended from Cumbrian and Scottish founders. Annual population monitoring of the reintroductions was undertaken. Nine years post-reintroduction, the level of population genetic variation was assessed using microsatellites. Variation in historical Cumbrian samples was determined using museum samples and Scottish samples from current populations were assayed to characterise natural population variation. Half of the Scottish sites also served as indicators of the alleles present in the founder populations. The genetic contribution of the founder populations allied to population size data allowed patterns of genetic variation to be modelled. Alleles from Cumbrian and Scottish founders are present in the reintroduced populations. The four sites have levels of variation akin to natural populations and exhibit differentiation as predicted by statistical modelling and comparable with natural populations. This suggests that reintroduction following captive breeding can produce self-sustaining populations with natural levels of genetic diversity. These populations appear to be undergoing the same evolutionary dynamics with bottlenecks and drift as natural populations.

Implications for insect conservation Reintroduction of captive bred individuals is a viable strategy for producing populations with natural levels of genetic diversity and evolutionary dynamics. Hybridisation of populations on the brink of extinction with those thriving can preserve some of the genetic distinctiveness of the declining population.
\end{abstract}

Keywords Reintroduction · Lepidoptera $\cdot$ Genetic variation · Population differentiation · Microsatellites $\cdot$ Euphydryas aurinia

\section{Introduction}

Reintroductions are commonly used in conservation to offset the ongoing decline in biodiversity (Seddon et al. 2007, 2012). Historically these were typically undocumented in the scientific literature (Schultz et al. 2008). However, this has changed since the turn of the millennium with reintroductions being the focus of various studies including monitoring (Wakamiya and Roy 2009; Bernardo et al. 2011; Nichols and

Michelle L. Davis

davism@edgehill.ac.uk

Department of Biology, Edge Hill University, Ormskirk, UK

2 Peterborough, UK
Armstrong 2012), management (Jones and Merton 2012; West et al. 2017), range expansion (Halley et al. 2012; Gaywood 2018) and population modelling (for summary see Armstrong and Reynolds 2012). The primary measure of the success of reintroductions is generally considered to be the establishment and successful breeding of a population and typically this is monitored for just a few years or until the emergence of the F1 or F2 generation (Wauters et al. 1997; Spalton et al. 1999; Richards and Short 2003; Sarrazin et al. 2008; Godefroid et al. 2011; Sanz and Grajal 2010).

Less commonly considered as a measure of success is the population genetic variation following reintroduction. Given that genetic variation provides the raw material upon which natural selection acts such variation is essential for the survivorship of a population (Lacy 1997). In the short term, a lack 
of genetic diversity causes inbreeding depression and other associated problems which can lead to population declines and increased extinction risk. In the long term it limits the ability of a species to adapt to changes in the environment such as climate or a novel pathogen (Allendorf et al. 2013). However, there is a notable absence of genetic considerations of reintroduction success in the literature.

Genetic assessments that do exist usually compare reintroduced and captive populations such as those in the lesser kestrel (Falco naumanni) (Alcaide et al. 2010); the blackfooted ferret (Mustela nigripes) (Wisely et al. 2008); American martens (Martes americana) (Hillman et al. 2017) and Griffon vulture (Gyps fulvus) (Le Gouar et al. 2008). Such studies have also been used to infer historic genetic patterns, including bottleneck events from modern populations (e.g., Alpine ibex (Capra ibex ibex) Biebach and Keller 2009) and to assess gene flow between reintroduced and natural populations (e.g., in eastern wild turkeys (Meleagris gallopavo silvestris), Latch and Rhodes 2005). Such examples reflect the vertebrate bias in the reintroduction literature (Groombridge et al. 2012). By comparison invertebrate reintroductions are rarely studied. Of the 349 reintroduction case studies published by the IUCN only $28(\sim 8 \%)$ feature invertebrates (Soorae 2018) and fewer still have assessed the genetic diversity of reintroduced invertebrate populations. From a population genetic and modelling perspective this lack of invertebrate studies is a lost opportunity given the vagility, discrete generation time and population monitoring possible with some invertebrates, most notably butterflies.

Within the UK there is a long, though poorly documented, history of amateur invertebrate reintroductions in the UK, mostly of butterfly species (Schultz et al. 2008). The majority of these reintroductions failed due to insufficient planning, poor habitat quality at release sites, limited release numbers and incomplete understanding of species' biology (Schultz et al. 2008). Nevertheless there have been successful invertebrate reintroductions in the UK, the best known being that of the Large Blue butterfly (Phengaris (=Maculinea) arion). Following extinction of the endemic UK subspecies $P$. a. eutyphron in 1979 , reintroduction was undertaken in 1984 with the Swedish subspecies (P. a. arion) following research to understand the species' life history and management requirements (Thomas et al. 1989). Further UK reintroductions of the Large Blue followed and the species is currently considered to be established and breeding in the UK (Thomas et al. 2009). Moreover after 19 generations the UK populations are now genetically differentiated from the Swedish donor populations and show differentiation between separate UK populations (Andersen et al. 2014).

While the Large Blue was always a species with limited distribution (Ford 1945; Asher et al. 2001), more widely dispersed butterfly species have experienced precipitous declines in the UK over the last 30 years prompting significant conservation concern. One such species is the Marsh Fritillary (Euphydryas aurinia), a univoltine species forming conspicuous larval webs in the early autumn and spring, found throughout much of Europe and presently classified as Least Concern by the IUCN, reflecting its broad geographical range. However it is declining throughout its range and regionally extinct in certain areas (van Swaay et al. 2010). The British Isles has been identified as a stronghold of the species with up to $15 \%$ of the European population. It is legally protected within Europe under the EU Habitats Directive, and in the UK since 1998 under the Wildlife and Countryside Act 1981.

Despite legal protections and conservation efforts it has still undergone significant declines in Britain over the past thirty years. This is due to changes in agricultural practices, including enrichment of pastures (Porter and Ellis 2011), leading to a decrease in suitable habitat for the larval food plant, Devil's-bit Scabious (Succisa pratensis) (Ridding et al. 2015).

One of the most heavily studied and historically important Marsh Fritillary populations was in Cumbria, in the northwest of England where it was widely dispersed (Ford and Ford 1930; Ford 1945; Porter and Ellis 2011). In the time before agricultural intensification, it was described as experiencing cyclical fluctuations in population size (Ford and Ford 1930). However from the 1980s it began to decline irreversibly and increasing local extinctions were noticed (Porter and Ellis 2011). The decline continued despite attempts to reverse it through management practices and two failed reintroductions (Porter and Ellis 2011).

By 2004, one population remained in Cumbria and only a single female was seen. Extensive surveying in autumn 2004 found just one larval web and the larvae were then taken into captivity with the intention of future reintroduction. As the larvae were the offspring of a single female and male, there was a concern that the resulting captive population would suffer from inbreeding depression. Hence the captive population was bred with individuals from the Argyll region of Scotland. This region was chosen because it housed healthy populations and the suggestion of historic gene flow between these populations and the Cumbrian (Porter and Ellis 2011). Thus, the captive Cumbrian adults were crossed with 95 individuals from 19 sites across the Argyll region (five larvae per site).

Reintroductions of the admixture population were carried out in 2007 across four sites (total 42,000 3rd stage instar larvae, 10,000 per site) which had been sympathetically managed prior to reintroduction (for details see (Porter and Ellis 2011)). Annual August population counts of larval webs reveal that all four reintroduction sites have persisted and are established (Porter and Ellis 2011). This persistence of the reintroductions implies success. However, their current genetic composition was unknown prior to this 
study and the establishment of four separate populations from the same initial genetic stock within a decade provides the opportunity to investigate the genetic differentiation of these populations. Moreover, the annual population estimates allied to the life history characteristics of the butterfly enable patterns of empirical population differentiation to be assessed against modelled variation.

An additional asset is the existence of historic Cumbrian specimens held in museums and private collections which date from both the pre-decline period (1920-1930s) and the final decline (1970-1993). These specimens present an opportunity to place the current level of population genetic variation in a historical context. A geographical and evolutionary context is possible by comparison of the reintroduced admixture that has formed the current population with that from the areas where the Scottish founder stock originated. The combination of historical specimens prior to local extinction, knowledge of the genetic constitution of the reintroduced populations, and samples from the areas that partly provided the material for the reintroductions, samples from current populations a decade after reintroduction alongside records of annual population estimates presents a unique opportunity to examine the fate of genetic variation in a reintroduced species. This study aims to determine: (1) if the four populations at the four original reintroduction sites have levels of genetic variation comparable with natural populations (2) how the genetic diversity of the reintroduced populations compares with both the historic one and with the Scottish donor populations. (3) the level of genetic differentiation between the four reintroduction sites after nine generations, 4) whether patterns of genetic variation in the reintroduced populations match the patterns predicted by computer modelling.

To the authors knowledge, this will be the first time a study has compared the genetic structure of an admixture reintroduced butterfly population with its two donor populations, one of which was the historic population at the reintroduction site. This will also be the first time that the genetic diversity of a reintroduced population has been compared to expected patterns of genetic diversity derived by computer modelling and based upon real population counts.

\section{Methods and materials}

\section{Site selection and field sample collection}

The sites used in this study are the four reintroduction sites described in Porter and Ellis (2011) (Fig. 1); due to the vulnerability of the sites to collection and the legal protection of the species the site names used to anonymise locations in that study will be retained here. Samples of larvae were collected in August 2016 under Natural England licence

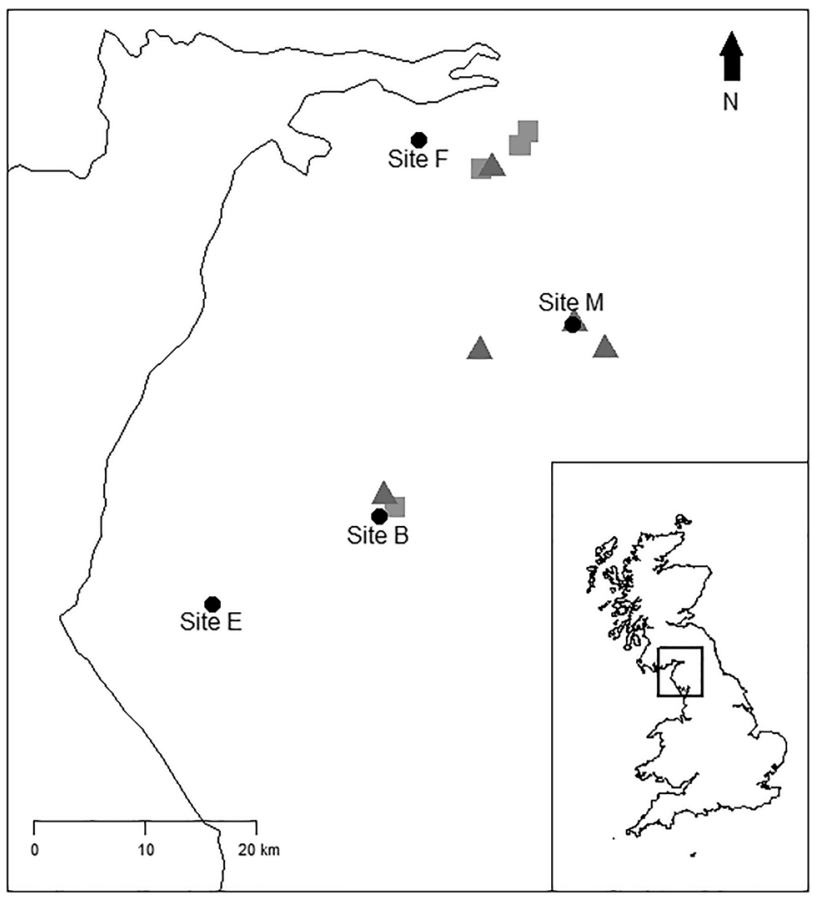

Fig. 1 The location of samples from Cumbria. Black indicates the reintroduction sites as described in Porter and Ellis (2011) which were sampled in this study. Grey indicates the original location of preserved specimens which were sampled. Note that one point may represent multiple specimens. Squares represent the eight specimens collected during 1920-1930 and triangles represent the 20 specimens collected 1970-1993

number 2016-25,165-SCI-SCI. A single larva per web was taken to prevent the collection of closely related individuals and a maximum of 30 larvae per site were collected as this was anticipated to give a fair representation of the genetic diversity at each site (Hale et al. 2012; Smee 2011).

Samples were collected from Scotland in August and September 2017 (under Scottish Natural Heritage licence number 104772) from four sites in the Argyll region (Fig. 2). It was not possible to sample the precise donor location due to the time that had elapsed since they were collected and the intermittent site occupancy by the species, given its metapopulation ecology (Junker et al. 2021). However, the broad geographical areas were known and two populations within these areas (Tayvallich and Mull) were sampled to represent the original Scottish donors. Two additional populations within the Argyll region but outside the original donor region (Islay and Oronsay) were also sampled for comparison. Sample collection was carried out as in Cumbria.

The original Cumbrian population was represented by historic specimens from the 1920-1930s held in museum collections (hereafter designated Cumbria Historic), plus specimens from the 1970-1990s and held in a private collection (designated Cumbria Donor), were sampled by removal of a leg with entomological forceps with permission from 


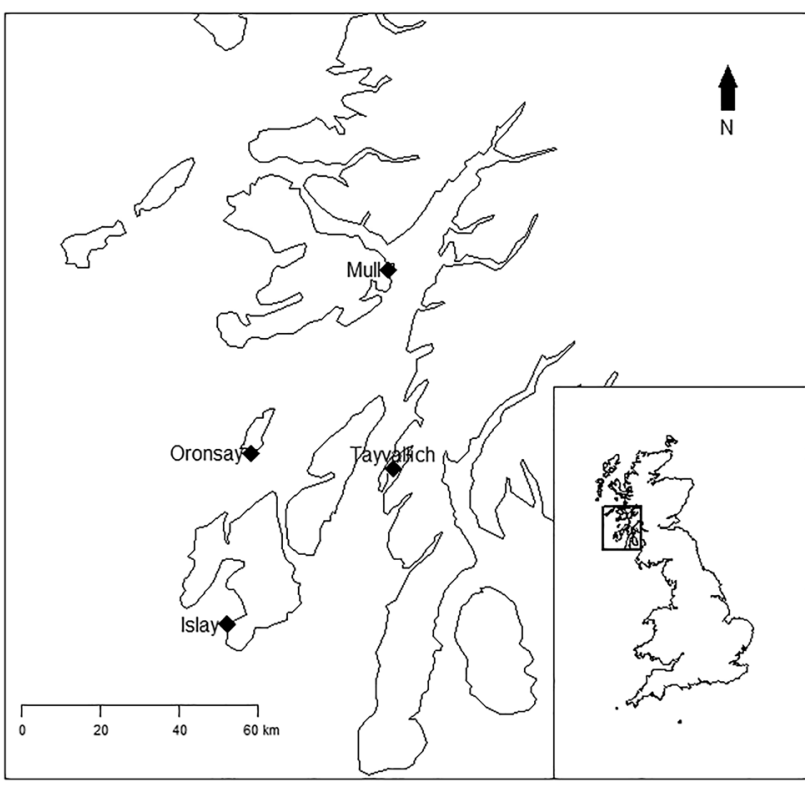

Fig. 2 Sampling sites in Scotland, Tayvallich and Mull were among the original nineteen donor sites for the Cumbria captive breeding project, Islay and Oronsey were not donor sites

the collectors or museum curators. These specimens were assigned to a geographical area based on the location information provided with the specimen (Fig. 1).

\section{DNA extraction and amplification}

Field collected specimens were stored at $-80^{\circ} \mathrm{C}$ until used. DNA was extracted from larval heads using DNeasy Blood and Tissue kit (Qiagen), following the standard protocol supplied by the manufacturer. For museum samples, DNA was extracted from the removed leg following the same protocol but with increased lysis time ( $12 \mathrm{~h}$ instead of $3 \mathrm{~h}$ ).

This work was undertaken using microsatellites. These are frequently used in invertebrate population genetics studies (Meng et al. 2008; Sigaard et al. 2008; Smee et al. 2013; Bogdanowicz et al. 2015; Nakahama and Isagi 2018) and utilise existing techniques to successfully extract DNA from preserved museum species (Harper et al. 2006; Wandeler et al. 2007; Watts et al. 2007).

Genotypes of all samples were scored using five microsatellites (Smee et al. 2013: Aurinia_01, Aurinia_13, Aurinia_45 and Aurinia_70; Sinama et al. 2011; Eau88), forward primers were fluorescently tagged with 6-FAM (Integrated DNA Technologies). PCR was carried out in $20 \mu \mathrm{l}$ reactions containing: $1.0 \mu \mathrm{l}$ template DNA, $4.0 \mu \mathrm{l}$ 5xPhusion High-Fidelity buffer (Thermo Scientific), $0.2 \mu 1$ Phusion DNA polymerase (Thermo Scientific), $4 \mu 110 \mathrm{mM}$ dNTP mix (containing $2.5 \mathrm{mM}$ of each) (Bioline), $0.6 \mu \mathrm{l}$ DMSO, $1 \mu 110 \mathrm{nM}$ of each primer, $2.5 \mu 110 \mathrm{nM} \mathrm{MgCl}_{2}$. Amplifications were carried out according to the following thermal profiles. For primers from Smee et al (2013): denaturing at $95{ }^{\circ} \mathrm{C}$ for $5 \mathrm{~min} ; 25$ cycles at $95{ }^{\circ} \mathrm{C}$ for $5 \mathrm{~s}, 60{ }^{\circ} \mathrm{C}$ $\left(62{ }^{\circ} \mathrm{C}\right.$ for Aurinia_16) for $30 \mathrm{~s}, 68^{\circ} \mathrm{C}$ for $1 \mathrm{~min}$; followed by 8 cycles at $95{ }^{\circ} \mathrm{C}$ for $5 \mathrm{~s}, 53{ }^{\circ} \mathrm{C}\left(55^{\circ} \mathrm{C}\right.$ for Aurinia_16) for $30 \mathrm{~s}, 68^{\circ} \mathrm{C}$ for $1 \mathrm{~min}$; and a final extension step of $72{ }^{\circ} \mathrm{C}$ for $30 \mathrm{~min}$. For Eau88: denaturing at $95{ }^{\circ} \mathrm{C}$ for $15 \mathrm{~min} ; 30$ cycles of $94{ }^{\circ} \mathrm{C}$ for $1 \mathrm{~min}, 56{ }^{\circ} \mathrm{C}$ for $1 \mathrm{~min}, 72{ }^{\circ} \mathrm{C}$ for $1 \mathrm{~min}$; and a final extension step of $60{ }^{\circ} \mathrm{C}$ for $45 \mathrm{~min}$.

PCR products were separated via capillary electrophoreses on an AB3500 Genetic Analyser (Applied Biosystems) and sized relative to an internal size standard (LIZ500; Applied Biosystems) using GeneMapper 5. Sizes were checked manually and individuals with unclear peaks were amplified and genotyped again. Due to the degraded nature of the preserved collection specimens, slightly greater leeway was allowed when genotyping, provided that clear peaks could be identified. A subset incorporating both field and museum samples were re-genotyped to ensure accuracy. Raw allele scores were binned using TANDEM to reduce error in the binning process.

\section{Statistical analysis}

The statistical power of the microsatellites to detect population differentiation was assessed in POWSIM 4.1 (Ryman and Palm 2006) using allele frequencies for the total dataset. $F_{S T}$ values were generated using an effective population size of 1000 individuals with 2000 iterations. The test showed the probably of detecting $F_{S T}$ of 0.01 or greater was $81 \%$ while the probability of detecting $F_{S T}$ of 0.02 or greater was $100 \%$.

Data analysis was carried out in $\mathrm{R}$ version 3.3.2 ( $\mathrm{R}$ Core Team 2021) using binned allele sizes unless otherwise stated. To characterise the genetic variation within populations' basic population statistics were calculated using diveRsity (Keenan et al. 2013). Pairwise $F_{S T}$ and Nei's $G_{S T}$ were calculated with corresponding p-values calculated using strataG to determine the level of differentiation between populations. Principle Component Analysis was used to analyse genetic structure of the reintroduced population with reference to the donor populations, this has been demonstrated to be a suitable analysis technique in admixture populations (Ma and Amos 2012). The analysis was carried out in Gstudio (Dyer 2012) and visualised with ggplot2 (Wickham 2009).

\section{Modelling}

As an aid in inference a forward-time population genetic simulation was written in Python using the simuPOP module (Peng and Kimmel 2005). This recreated the demographic history of the populations under study as closely as possible, but did not include mutation, selection or gene flow. Similar 
results to the empirical data will suggest that drift alone is enough to generate the population differentiation observed. A total of 1000 replicate simulations were run.

\section{Simulation outline}

The simulation used five loci with similar levels of genetic variation to the empirical data. This utilised an initial nineteen source populations each with $10^{4}$ individuals and a 2:1 male: female sex ratio (based on the work of Schtickzelle et al. (2005) and Zimmermanet al. (2011a)) All loci were assigned five alleles randomly selected from a list of possible allelic states based on the empirical data for source populations (eight to twelve, depending on locus). Frequencies of each allele were also randomly assigned. A twentieth population with only one male and one female individual was also created to represent the Cumbrian remnant. Loci therein were randomly assigned only three alleles, again with randomly generated frequencies. Source populations underwent a bottleneck down to five individuals and were merged before breeding began (for a total of 97 individuals at generation zero). For two generations thereafter, random monogamous mating events occurred, each producing 300 offspring (with a $66 \%$ chance of being male), until a carrying capacity of $5 \times 10^{4}$ individuals was reached. Prior to the fourth generation's mating events, the population was split into four groups of $1.5 \times 10^{4}$ individuals, representing the initial Cumbrian reintroductions (the remaining 8000 were discarded from the model). After this, random mating proceeded for a further twelve generations, but the number of mating events varied according to empirical census data (Fig. 5b). That is, mating events occurred with 30 offspring each until the simulated population sizes matched the observed number of webs that year multiplied by 30 (giving a $10 \%$ survival rate based on larval survival rates in related Euphydryas species (Ehrlich et al. 1975; Kuussaari et al. 2004) and taking into account the reported effects of parasitoid attack (Porter 1981; Bulman 2001) which is assumed to be absent due the extinction of the parasitoid in Cumbria following the extinction of the host population).

However, census numbers for Site M post-generation three were too low to produce enough offspring to reach the desired size in generation five. Therefore, this number was increased to five individuals to allow the simulation to proceed. Similarly, one run of the simulation $(0.1 \%)$ was aborted due to a lack of mate availability, which meant that with a fixed number of offspring and monogamous mating, there were insufficient pairings to produce a target population size. As the goal was to assess the potential impacts of a specific demographic history on genetic variation, that run was therefore discarded.

All model populations were randomly sampled at each generation $(n=30)$, a sample size comparable to the empirical data. Median heterozygosity across loci-both observed and expected - was determined across sites, and finally across runs. Median pairwise $F_{S T}$ between populations was also calculated from these samples (Weir and Cockerham 1984).

\section{Results}

\section{Reintroduced population genetic diversity}

All Cumbrian reintroduction sites showed significant heterozygote deficiency (Table 1). Private alleles were observed at each site, accounting for $7.14-10.71 \%$ of observed alleles at a regional level. No significant level of inbreeding $\left(F_{I S}\right)$ was detected. Pairwise $F_{S T}$ values (Table 2) are mostly significant, the exception is between Site B and Site $M$ which is non-significant. $G_{S T}{ }_{S T}$ values, which are standardised to take into account variation in diversity at different loci, show a similar pattern to the $F_{S T}$ scores.

The Principal Component Analysis (Fig. 3) showed no clear separation between all four reintroduced populations. However, Site M shows little overlap with Site F and Site E. Site B shows extensive overlap with both Site F, Site E and Site M, reflected in the lowest pairwise FST values and the lack of significant FST between Sites B and M.

\section{Comparison with founder populations}

The Cumbrian reintroduction sites show higher allele number, richness and $F_{I S}$ compared with the Scottish populations (Table 1). Scotland shows a higher occurrence of private alleles than Cumbria, but Cumbria does contain private alleles which are absent from the Scottish populations. The original Cumbrian population also contains private alleles absent from the reintroduced population or Scotland. When the time periods are considered separately, it can be seen that the original Cumbrian private alleles are restricted to the earlier time period (1920-1930). Nevertheless, the high incidence of shared alleles leads the two time periods to largely cluster together on the PCA (Fig. 4).

Scottish donor and non-donor sites showed similar levels of diversity and variation. Pairwise $F_{S T}$ and $G_{S T}$, values between the Cumbrian reintroduced population and the donor populations are lower than between Cumbria and nondonor populations (Table 3).

PCA comparison between the reintroduced population and the populations which represent the two parts of the founder population show that separation between all three groups is almost complete (Fig. 4). The Scottish samples are separated completely from all Cumbrian material on PC1. The reintroduced population is distinct from the historic Cumbrian populations on the $\mathrm{PC} 2$ axis, with the exception 
Table 1 Genetic diversity statistics for Cumbrian reintroduction sites, original Cumbrian populations (Donor (1970s-1990s) and Historic (19201930)) and Scottish sites (non-donor sites in italics), mean values across all loci shown

\begin{tabular}{|c|c|c|c|c|c|c|c|c|}
\hline \multirow[t]{2}{*}{ Region } & \multirow[t]{2}{*}{ Site } & \multirow[t]{2}{*}{ Sample size } & \multirow[t]{2}{*}{ Allelic richness } & \multicolumn{2}{|c|}{ Private alleles $(\%)$} & \multirow[t]{2}{*}{ Ho } & \multirow[t]{2}{*}{$\mathrm{He}$} & \multirow[t]{2}{*}{$F_{I S}(95 \% \mathrm{CI})$} \\
\hline & & & & Region & Total & & & \\
\hline Cumbria & Site B & 30 & 5.41 & 9.67 & 6.45 & 0.43 & 0.63 & $0.310(0.186,0.434)$ \\
\hline Cumbria & Site E & 29 & 4.87 & 10.71 & 10.71 & 0.38 & 0.55 & $0.297(0.156,0.429)$ \\
\hline Cumbria & Site F & 30 & 4.65 & 7.4 & 7.4 & 0.49 & 0.56 & $0.114(-0.020,0.251)$ \\
\hline Cumbria & Site M & 23 & 4.84 & 7.14 & 3.57 & 0.51 & 0.61 & $0.172(0.003,0.316)$ \\
\hline Cumbria & Donor & 20 & 2.8 & 28.57 & 0 & 0.56 & 0.65 & $0.149(-0.074,0.351)$ \\
\hline Cumbria & Historic & 8 & 3.1 & 21.05 & 10.52 & 0.47 & 0.71 & $0.340(0.076,0.559)$ \\
\hline Scotland & Islay & 22 & 2.89 & 0 & 0 & 0.44 & 0.43 & $-0.021(-0.180,0.137)$ \\
\hline Scotland & Mull & 12 & 3.18 & 11.11 & 5.55 & 0.47 & 0.52 & $0.096(-0.169,0.326)$ \\
\hline Scotland & Oronsay & 30 & 3.58 & 16 & 8 & 0.42 & 0.51 & $0.166(0.036,0.289)$ \\
\hline Scotland & Tayvallich & 30 & 4.19 & 19.23 & 15.38 & 0.52 & 0.63 & $0.174(0.029,0.305)$ \\
\hline Cumbria reintroduction & & 112 & 4.24 & & 15.78 & 0.44 & 0.62 & $0.287(0.218,0.350)$ \\
\hline Cumbria original & & 28 & 4.38 & & 28 & 0.54 & 0.68 & $0.213(0.050,0.357)$ \\
\hline Scotland & & 94 & 3.73 & & 37.14 & 0.47 & 0.6 & $0.220(0.151,0.289)$ \\
\hline
\end{tabular}

Allelic richness is calculated using 1000 resamples $(\mathrm{n}=$ smallest input sample size), with replacement per populations. Private alleles are given as the percentage of that regions alleles across all loci found only in that population. $\mathrm{H}_{\mathrm{e}}$ expected and $\mathrm{H}_{\mathrm{o}}$ observed heterozygosity

Italics indicate that the site was not a donor site for the Cumbrian captive breeding and reintroduction program

Table 2 Pairwise $F_{S T}$ (below) and $G_{S T}^{\prime}$ (above) for sites sampled in Cumbria $(\mathbf{a}, \mathrm{n}=112)$ and Scotland $(\mathbf{b}, \mathrm{n}=94)$

\begin{tabular}{|c|c|c|c|c|}
\hline $\mathbf{a}$ & $\begin{array}{l}\text { Site B } \\
(\mathrm{n}=30)\end{array}$ & $\begin{array}{l}\text { Site E } \\
(n=29)\end{array}$ & $\begin{array}{l}\text { Site F } \\
(n=30)\end{array}$ & $\begin{array}{l}\text { Site M } \\
(n=23)\end{array}$ \\
\hline Site B & - & $0.0204 * *$ & $0.0441 * * *$ & -0.0097 \\
\hline Site E & $0.0405^{* *}$ & - & $0.0561 * * *$ & $0.1004 * * *$ \\
\hline Site F & $0.0609 * * *$ & $0.0705 * * *$ & - & $0.1147 * * *$ \\
\hline Site M & 0.0158 & 0.1186 *** & $0.1257 * * *$ & - \\
\hline $\mathrm{b}$ & $\begin{array}{l}\text { Islay } \\
(\mathrm{n}=22)\end{array}$ & $\begin{array}{l}\text { Mull } \\
(n=12)\end{array}$ & $\begin{array}{l}\text { Oronsay } \\
(\mathrm{n}=30)\end{array}$ & $\begin{array}{l}\text { Tayvallich } \\
(\mathrm{n}=30)\end{array}$ \\
\hline Islay & - & $0.0767 * *$ & $0.0959 * *$ & $0.1512 * * *$ \\
\hline Mull & $0.1185^{* *}$ & - & $0.0811 * *$ & $0.0711 * * *$ \\
\hline Oronsay & $0.0769 * * *$ & $0.1158 * *$ & - & $0.0883 * * *$ \\
\hline Tayvallich & $0.1495 * * *$ & $0.1033 * * *$ & $0.0924 * * *$ & - \\
\hline
\end{tabular}

Significance: $* \mathrm{p}<0.05 ; * * \mathrm{p}<0.01 ; * * * \mathrm{p}<0.001$

of one point. There is no separation between donor and nondonor sites in the Scottish clustering and both show comparable levels of genetic diversity.

\section{Simulation}

Simulations generated broadly similar levels of genetic diversity and population differentiation as those estimated from empirical data (Fig. 5a, c). Median observed heterozygosity was consistently higher than expected from the simulation (Fig. 5c; Table 1). Overall median pairwise $F_{S T}$ increased as the simulations progressed and at the equivalent generation (12) was slightly lower than that calculated in this study $\left(F_{S T}=0.031\right.$ and $F_{S T}=0.066$, respectively; Fig. 5a; Table 2). Differentiation was however variable between runs, ranging from effectively identical (less than zero) to 0.237 by the end of the simulation (Fig. 5a). The smallest population, Site M, had the highest levels of differentiation consistently (throughout all replicates) after only one generation post-reintroduction (Fig. 5a). 


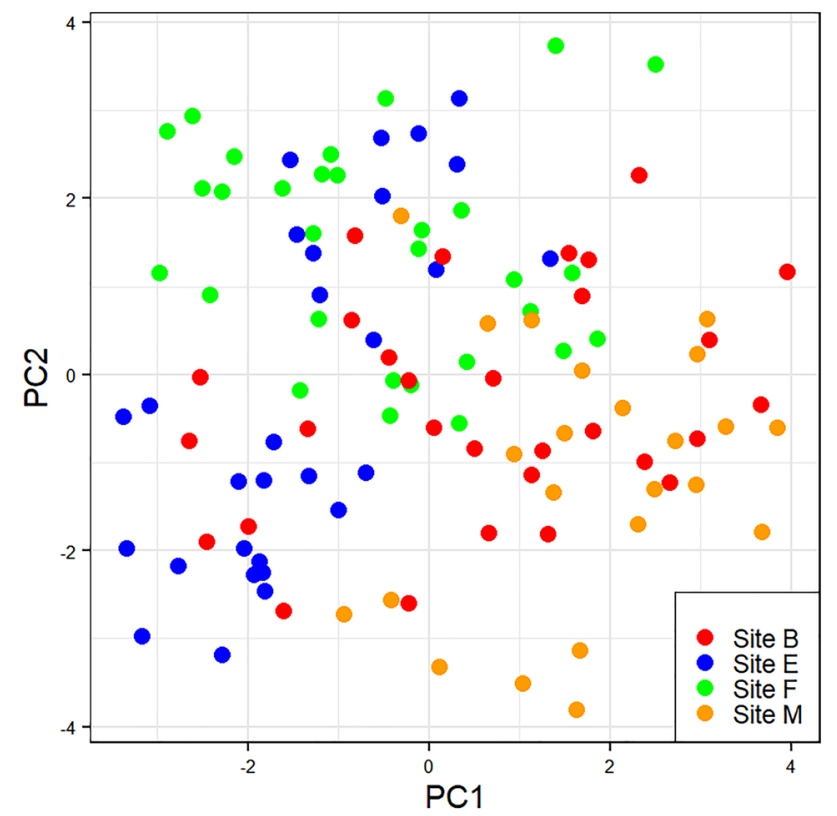

Fig. 3 Principal component analysis for the reintroduced sites in Cumbia, each point represents an individual collected from that site

\section{Discussion}

The ultimate measure of success of a reintroduction programme is to restore populations that exhibit sufficient evolutionary dynamism to survive pressures from both natural selection and stochastic processes (Seddon et al. 2012; Armstrong and Reynolds 2012; Robert et al. 2015). From a variety of perspectives the Cumbrian Marsh Fritillary reintroduction programme meets this criterion of success. All four of the reintroduction sites display similar levels of genetic variation. These are greater than the levels of variation displayed in the four Argyll sites. This may be due to the diverse origins of the reintroductions, incorporating nineteen Scottish sites plus the captive Cumbrian individuals. Comparable high levels of genetic diversity in translocated populations were found in the hihi (Notiomystis cincta), a New Zealand endemic bird (Brekke et al. 2011).

Genetic swamping, the total replacement of the local genotypes with incoming genotypes (Lenormand 2002) is a concern with some reintroduced populations (Veale and Russello 2016). Despite the disproportionate number of alleles contributed by the Scottish founders, potentially a maximum of 190 alleles per locus compared to maximum of four per locus for the Cumbrian founders, this has not occurred in the Cumbrian reintroduction. The clear separation of the reintroduced and Scottish populations in the PCA plot, alongside the slight overlap on the $\mathrm{PC} 2$ axis, between the historic Cumbrian and reintroduced populations, provides evidence of the persistence of Cumbrian specific alleles.

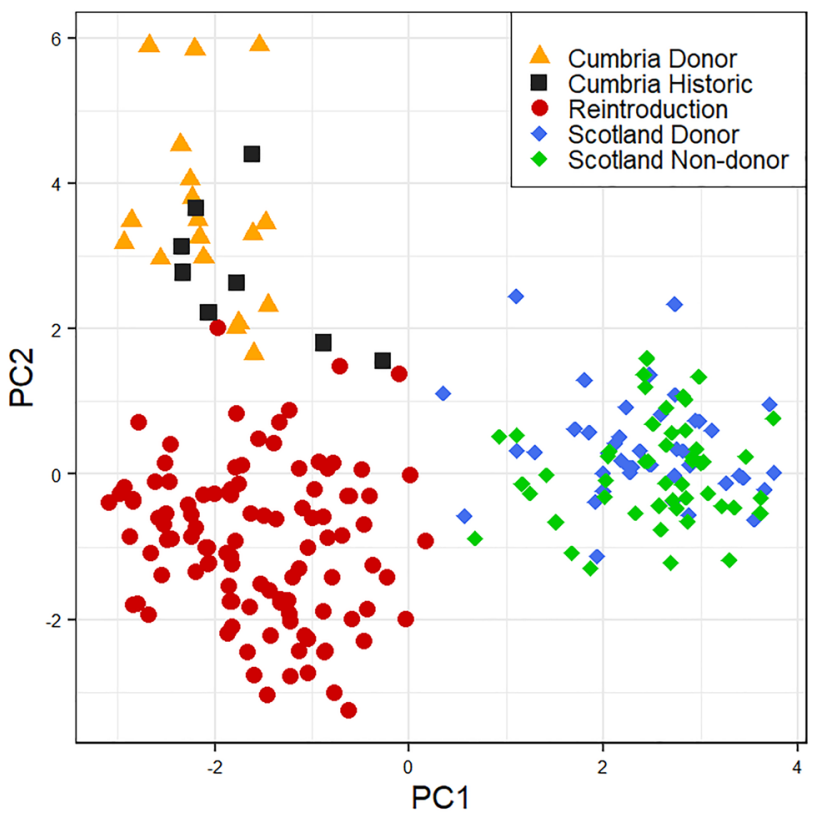

Fig. 4 Principal component analysis of the reintroduced populations in Cumbria, the Scottish donor and non-donor populations and the historic Cumbrian samples

The occurrence of $15.78 \%$ private alleles in the reintroduced Cumbrian populations, absent from the Argyll sites may be due to one or more of three factors: mutation in the markers; the alleles are at low frequency in Argyll and were not detected in this survey, or the alleles are unique to Cumbria and demonstrate the persistence of the original Cumbrian population, either in the form of alleles preserved in the captive population or in previous undetected wild populations that have interbred with the reintroduced populations. Despite the relatively high mutation rate of microsatellites the low generation number makes it unlikely that this phenomenon will account for this genetic distinctiveness (Ellegren 2009; Bhargava and Fuentes 2010).

The persistence of a previously undetected Cumbrian population of sufficient size to contribute such an amount of private alleles is highly unlikely given the close monitoring of the species in the region over the decades from decline to extinction (Porter and Ellis 2011). There are also no reported occurrences of the species outside of the reintroduction sites or adjacent areas (CMFAG, pers. comm.). Nor is it possible that these are entirely due to the contribution of the Cumbrian founders to the captive breeding, as these are all suspected to be the offspring of a single pair (Porter and Ellis 2011) and thus at most only a few alleles per locus could have been contributed. Given that the populations had been declining for a number of years it is likely that the actual number of unique alleles contributed by the Cumbrian founders was markedly less due to the effects of inbreeding.

The most likely cause of the high number of private alleles in the reintroduced population and the resultant 
Table $3 F_{S T}(\mathbf{a})$ and $G_{S T}^{\prime}(\mathbf{b})$ within an area (italic) and pairwise between areas

\begin{tabular}{|c|c|c|c|}
\hline $\mathbf{a}$ & $\begin{array}{l}\text { Cumbria reintroduced } \\
(\mathrm{n}=112)\end{array}$ & $\begin{array}{l}\text { Scotland donor } \\
(\mathrm{n}=42)\end{array}$ & $\begin{array}{l}\text { Scotland non-donor } \\
(\mathrm{n}=52)\end{array}$ \\
\hline Cumbria reintroduced & $0.0673 * * *$ & & \\
\hline Scotland donor & $0.2316^{* * *}$ & $0.1133 * * *$ & \\
\hline Scotland non-donor & $0.3090 * * *$ & $0.0803 * * *$ & $0.0705^{* *}$ \\
\hline $\mathrm{b}$ & $\begin{array}{l}\text { Cumbria reintroduced } \\
(\mathrm{n}=112)\end{array}$ & $\begin{array}{l}\text { Scotland donor } \\
(\mathrm{n}=42)\end{array}$ & $\begin{array}{l}\text { Scotland non-donor } \\
(\mathrm{n}=52)\end{array}$ \\
\hline Cumbria reintroduced & $0.0654 * * *$ & & \\
\hline Scotland donor & $0.2224 * * *$ & $0.0919 * * *$ & \\
\hline Scotland non-donor & $0.3210 * * *$ & $0.0686 * * *$ & $0.0904 * *$ \\
\hline
\end{tabular}

Scottish donor sites which provided founders for the Cumbrian captive breeding project are Tayvallich and Mull. The non-donor sites comprise Islay and Oronsey

Significance: $* \mathrm{p}<0.05 ; * * \mathrm{p}<0.01 ; * * \mathrm{p}<0.001, \mathrm{~N}=206$
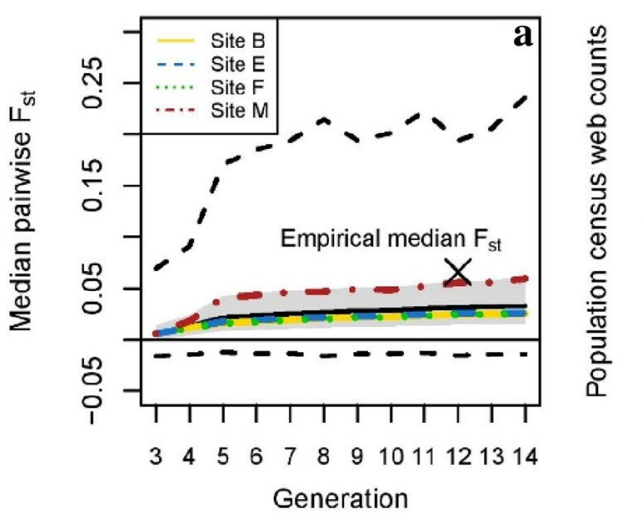

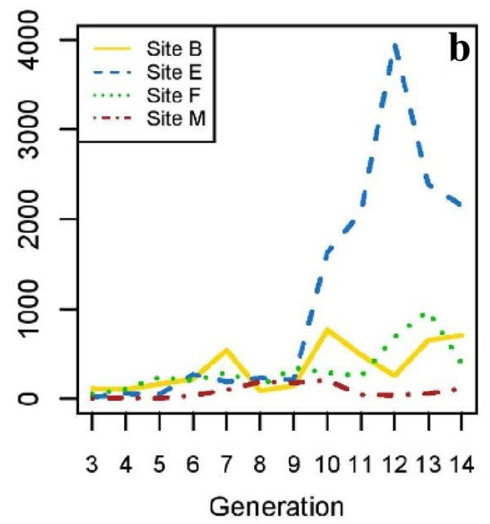

Fig. 5 Results and parameters of a forward-time individual based population genetics simulation, written in Python using the simuPOP module (Peng and Kimmel 2005). This was designed to mimic the captive breeding, introduction and demographic history of breeding in the wild of the reintroduced populations. a Typical population differentiation as median pairwise $F_{S T}$ between all four populations post-reintroduction (generations one and two represent captive breeding and are therefore not included). The solid black line is median $F_{S T}$ across all comparisons while the shaded polygon is interquartile range of this distribution. Dashed black lines represent minimum and

separation between the Argyll and reintroduced populations on the PCA is the composition of the Argyll founders of the captive breeding population. The Argyll component was collected from 19 donor sites of which this study resampled only two, most donor sites no longer hosting the species. Consequently approximately $90 \%$ of the potential genetic variation from the Argyll founders is not being represented in this analysis. Despite this, pairwise comparison has shown that Cumbrian populations have a lower degree of differentiation from the Scottish donor populations than from the non-donor populations, suggesting that the Argyll dataset is at least partly representative of the founders used for the reintroduction. maximum $F_{S T}$ calculated. Coloured lines represent median $F_{S T}$ for all comparisons that include the population indicated by the legend. $\mathbf{b}$ Population size for all 'wild' breeding generations, based on empirical data derived from web censuses. c Typical genetic diversity as median observed and expected heterozygosity across all populations throughout the simulation post-reintroduction. The lines represent maximum, median and minimum heterozygosity (from top to bottom); the legend indicates whether these are observed or expected. The shaded polygons represent the interquartile range for each distribution

It is also worth recognising that allele frequencies change over time due to natural processes. Approximately $10 \%$ of the alleles found in the 1920-1930 Cumbrian samples are not found in any other population, including the 1970-1990 Cumbrian material, their loss probably being due to one or more bottlenecks in the intervening period. Comparable comparisons of historic and current levels of genetic diversity are rare, probably due to the challenges of working with ancient DNA (Nicholls 2005; Bi et al. 2013; Burrell et al. 2015). However a similar loss of genetic diversity and of particular alleles between historic and present populations has been documented in the African lion (Panthera leo) in the Kavango-Zambezi conservation area (Dures et al. 2019). 
In the nine generations since the reintroduction was undertaken, some degree of genetic differentiation between the reintroduced populations, akin to that between natural populations, is shown by the pairwise comparison between Cumbrian sites being comparable to those within Argyll. Given that microsatellite markers are selectively neutral (Smee et al. 2013), selection pressures are unlikely to be the cause of population differentiation. Moreover as the populations have only been separate for nine generations it is unlikely that there has been time for sufficient mutations to occur to account for this differentiation (Ellegren 2000). Therefore, the most probable cause is genetic drift. The modelling suggests that the reintroduced populations are behaving genetically as would be expected based on the recorded population sizes and allele frequencies. The simulation shows that drift is sufficient to generate differentiation of this magnitude in a short timeframe. The $F_{S T}$ increases with time after reintroduction (Fig. 5a), demonstrating that drift has an ongoing role in shaping genetic structure rather than the initial founder effects that create the differentiation. Genetic drift has the greatest effect in small populations (Willi et al. 2007; Whitlock 2010). Site M would be particularly prone to drift since in annual surveys following the initial reintroduction Site $\mathrm{M}$ had the lowest web count compared to the other three sites (Porter and Ellis 2011; CMFAG, pers. comm.). This is likely to account for the highest pairwise scores between Site M and Site E and Site F. This is also reflected in the results from the simulation, where the site was consistently the most distinct from other populations after only one generation of breeding post-reintroduction. The lack of differentiation between Site $\mathrm{M}$ and Site B reflects the greater variation in Site B. Differentiation may reasonably be expected to occur in the future.

Similar population differentiation has been seen in the reintroduced populations of the large blue butterfly (Phenargis arion) in the UK as all populations have similar levels of genetic diversity but differing allele frequencies (Andersen et al. 2014), a probable product of the two decades between the reintroduction and genetic study. On the other hand, a study of two locally reintroduced Maculinea spp. in Netherlands found no significant population differentiation after five generations (Wynhoff 2001). Comparable levels of genetic differentiation between natural and reintroduced populations were observed in the Griffon vulture (Gyps ful$v u s$ ) after approximately eight generations (Le Gouar et al. 2008) and in the hihi (Notiomystis cincta) four to nine generations after reintroduction (Brekke et al. 2011).

\section{Conclusion and management implications}

This study has shown that reintroduction following captive breeding is capable of resulting in self-sustaining populations which behave and respond at a population level in a similar manner to natural populations. The study has further demonstrated that a combination of genetic work, modelling and population monitoring alongside an understanding of the species' biology can reveal the evolutionary dynamics of the reintroduction and its potential for future success. Such an approach may be valid in other species. The rather radical approach of hybridising the last remaining Cumbrian individuals with Scottish stock has to some degree preserved some of the distinction of the Cumbrian population (Fig. 4).

Based on the findings of this study it is recommend that no further genetic management (e.g., translocations or populations supplementations) of the Cumbrian population is undertaken at this time, none of the reintroduced populations studied are at risk of inbreeding depression and as new colonies are establishing naturally (Phoenix 2018) it is reasonable to assume that gene flow between the reintroduced populations will also naturally establish with time as has been seen following reintroductions in other species (Le Gouar et al. 2008). Such establishment of a natural metapopulation structure was seen following the introduction of the Bog Fritillary (Proclossiana eunomia) to a site in Morvan, France (Nève et al. 1996; Nève et al. 2008). The mark release recapture distances observed by Nève et al. (1996) for the Bog Fritillary are on avergae similar to those observed for the Marsh Fritillary (Zimmermann et al. 2011b) with some longer distance $(>10 \mathrm{~km})$ dispersals seen in the Marsh Fritllary, therefore a similar establishment of a natureal metapopulation struture in Cumbria should be expected to occure with time.

On a broader scale, it is recommended that the managers of other declining populations of the Marsh Fritillary strongly consider adopting this management strategy, and if necessary the captive breeding methodology, used in Cumbria (for details see Porter and Ellis 2011). A captive breeding programme for the Apollo butterfly (Parnassius apollo) in Poland resulted in an increase in wing malformations suspected to be at least in part due to the small founder population of approximately 20 individuals resulting in the increased frequency of deleterious recessive alleles in genes such as wingless, although this has not been confirmed (Pierzynowska et al. 2019). This is similar to what could have occurred in Cumbria had the captive breeding programme been instituted sooner, while multiple sibling larval web remained, and therefore without the clear and obvious need for the additional Scottish founder stock. Where a population is not in immediate danger of extinction, captive breeding may be unnecessary, and a similar genetic rescue could be carried out by releasing late-stage instar larvae, collected from a suitable donor population, at the site which is either known or suspected to have low levels of genetic diversity. A low level of gene flow, represented by a few individuals from external sources breeding successfully each year, is thought 
to be sufficient to avoid inbreeding depression while still retaining any locally advantageous adaptations (Åkesson et al. 2016; Gustafson et al. 2017). This strategy, including the genetic rescue, should also be considered for other Lepidoptera which have similar life histories and conservation concerns (Frankham 2015; Ralls et al. 2018).

Acknowledgements The authors are grateful to the members of the Cumbrian Marsh Fritillary Action Group for their support in field work and access to reintroduction sites. We are grateful to curators of Tullie House Museum and the Natural History Museum for access to their collections and to Tim Melling and Peter Summers for allowing sampling of their private collections.

Author contributions All authors contributed to the study conception and design. Material collection was performed by MD and KP. Laboratory work and data analysis were performed by MD. Computer modelling was performed by $\mathrm{CB}$. The first draft of the manuscript was written by MD and all authors commented on previous versions of the manuscript. All authors read and approved the final manuscript.

Funding This work was funded by Edge Hill University as part of an internal PhD Studentship.

Data availability Not applicable.

Code availability Not applicable.

\section{Declarations}

Conflict of interest The authors have no conflicts of interest to declare that are relevant to the content of this article.

Ethical approval The authors confirm that they follow the rules of good scientific practice and all ethical standards requested by the journal. Collection of live samples was carried out with licence from appropriate governmental bodies and in an approved and appropriate manner.

Open Access This article is licensed under a Creative Commons Attribution 4.0 International License, which permits use, sharing, adaptation, distribution and reproduction in any medium or format, as long as you give appropriate credit to the original author(s) and the source, provide a link to the Creative Commons licence, and indicate if changes were made. The images or other third party material in this article are included in the article's Creative Commons licence, unless indicated otherwise in a credit line to the material. If material is not included in the article's Creative Commons licence and your intended use is not permitted by statutory regulation or exceeds the permitted use, you will need to obtain permission directly from the copyright holder. To view a copy of this licence, visit http://creativecommons.org/licenses/by/4.0/.

\section{References}

Åkesson M, Liberg O, Sand H, Wabakken P, Bensch S, Flagstad Ø (2016) Genetic rescue in a severely inbred wolf population. Mol Ecol 25:4745-4756. https://doi.org/10.1111/mec.13797

Alcaide M, Negro JJ, Serrano D, Antolín JL, Casado S, Pomarol M (2010) Captive breeding and reintroduction of the lesser kestrel
Falco naumanni: a genetic analysis using microsatellites. Conserv Genet 11:331-338. https://doi.org/10.1007/s10592-009-9810-7

Allendorf FW, Luikart G, Aitken SN (2013) Conservation and the genetics of populations, 2nd edn. John Wiley and Sons, Chinchester

Andersen A, Simcox DJ, Thomas JA, Nash DR (2014) Assessing reintroduction schemes by comparing genetic diversity of reintroduced and source populations: a case study of the globally threatened large blue butterfly (Maculinea arion). Biol Conserv 175:34-41. https://doi.org/10.1016/j.biocon.2014.04.009

Armstrong DP, Reynolds MH (2012) Modelling reintroduced populations: the state of the art and future directions. Reintroduction biology: integrating science and management. John Wiley and Sons, Ltd, Chichester, UK, pp 165-222

Asher J, Warren MS, Fox R, Harding P, Jeffcoate G, Jeffcoate S (2001) The millennium atlass of butterflies on Britain and Ireland. Oxford Univeristy Press, Oxford

Bernardo CSS, Lloyd H, Olmos F, Cancian LF, Galetti M (2011) Using post-release monitoring data to optimize avian reintroduction programs: a 2-year case study from the Brazilian Atlantic Rainforest. Anim Conserv 14:676-686. https://doi.org/10.1111/j.1469-1795. 2011.00473.x

Bhargava A, Fuentes FF (2010) Mutational dynamics of microsatellites. Mol Biotechnol 44:250-266. https://doi.org/10.1007/ s12033-009-9230-4

Bi K, Linderoth T, Vanderpool D, Good JM, Nielsen R, Moritz C (2013) Unlocking the vault: next-generation museum population genomics. Mol Ecol 22:6018-6032. https://doi.org/10. $1111 / \mathrm{mec} .12516$

Biebach I, Keller LF (2009) A strong genetic footprint of the reintroduction history of Alpine ibex (Capra ibex ibex). Mol Ecol 18:5046-5058. https://doi.org/10.1111/j.1365-294X.2009. 04420.x

Bogdanowicz SM, Mastro VC, Prasher DC, Harrison RG (2015) Microsatellite DNA variation among Asian and North American Gypsy Moths (Lepidoptera: Lymantriidae). Ann Entomol Soc Am 90:768-775. https://doi.org/10.1093/aesa/90.6.768

Brekke P, Bennett PM, Santure AW, Ewen JG (2011) High genetic diversity in the remnant island population of hihi and the genetic consequences of re-introduction. Mol Ecol 20:29-45. https://doi.org/10.1111/j.1365-294X.2010.04923.x

Bulman CR (2001) Conservation biology of the marsh fritillary butterfly Euphydryas aurinia. Univeristy of Leeds, Leeds, UK

Burrell AS, Disotell TR, Bergey CM (2015) The use of museum specimens with high-throughput DNA sequencers. J Hum Evol 79:35-44. https://doi.org/10.1016/j.jhevol.2014.10.015

Dures SG, Carbone C, Loveridge AJ, Maude G, Midlane N, Aschenborn O, Gottelli D (2019) A century of decline: loss of genetic diversity in a southern African lion-conservation stronghold. Divers Distrib 25:870-879. https://doi.org/10.1111/ddi.12905

Dyer RJ (2012) The gstudio package. Virginia Virginia Commonw Univ

Ehrlich PR, White RR, Singer MC, Mckechnie SW, Gilbert LE (1975) Checkerspot butterflies: a historical perspective. Science 80(188):221-228. https://doi.org/10.1126/science.1118723

Ellegren H (2000) Microsatellite mutations in the germline: implications for evolutionary inference. Trends Genet 16:551-558. https://doi.org/10.1016/S0168-9525(00)02139-9

Ellegren H (2009) A selection model of molecular evolution incorporating the effective population size. Evolution (new York) 63:301-305. https://doi.org/10.1111/j.1558-5646.2008.00560.x

Ford EB (1945) The new naturalist butterflies. Collins, London

Ford HD, Ford EB (1930) Fluctuations in numbers and its influence on variation in Melitaea aurinia Rott. (Lepidoptera). Trans R Entomol Soc London 78:345-352. https://doi.org/10.1111/j. 1365-2311.1930.tb00392.x 
Frankham R (2015) Genetic rescue of small inbred populations: meta-analysis reveals large and consistent benefits of gene flow. Mol Ecol 24:2610-2618. https://doi.org/10.1111/mec.13139

Gaywood MJ (2018) Reintroducing the Eurasian beaver Castor fiber to Scotland. Mamm Rev 48:48-61

Godefroid S, Piazza C, Rossi G, Buord S, Stevens A-D, Aguraiuja R, Cowell C, Weekley CW, Vogg G, Iriondo JM, Johnson I, Dixon B, Gordon D, Magnanon S, Valentin B, Bjureke K, Koopman R, Vicens M, Virevaire M, Vanderborght T (2011) How successful are plant species reintroductions? Biol Conserv 144(2):672-682. https://doi.org/10.1016/j.biocon.2010.10.003

Groombridge JJ, Raisin C, Bristol R, Richardson DS (2012) Genetic consequences of reintroductions and insights from population history. Reintroduction biology: integrating science and management. John Wiley and Sons, Ltd, Chichester, pp 395-440

Gustafson KD, Vickers TW, Boyce WM, Ernest HB (2017) A single migrant enhances the genetic diversity of an inbred puma population. R Soc Open Sci 4:170115. https://doi.org/10.1098/ rsos. 170115

Hale ML, Burg TM, Steeves TE, Poon AFY (2012) Sampling for microsatellite-based population genetic studies: 25 to 30 individuals per population is enough to accurately estimate allele frequencies. PLoS ONE 7(9):e45170. https://doi.org/10.1371/journ al.pone. 0045170

Halley D, Rosell F, Saveljev A (2012) Population and distribution of Eurasian beaver (Castor fiber). Balt for 18:168-175

Harper GL, Maclean N, Goulson D (2006) Analysis of museum specimens suggests extreme genetic drift in the adonis blue butterfly (Polyommatus bellargus). Biol J Linn Soc 88:447-452. https:// doi.org/10.1111/j.1095-8312.2006.00632.x

Hillman TL, Keenlance P, Moore JA, Swanson BJ, Jacquot JJ, Witt JC, Cornman A (2017) Genetic diversity of reintroduced American martens in Michigan's Lower Peninsula. J Mammal 98:1489-1496. https://doi.org/10.1093/jmammal/gyx075

Jones CG, Merton DV (2012) A tale of two islands: the rescue and recovery of endemic birds in new zealand and mauritius. Reintroduction biology: integrating science and management. John Wiley and Sons, Ltd, Chichester, UK, pp 33-72

Junker M, Konvicka M, Zimmermann K, Schmitt T (2021) Geneflow within a butterfly meta population: the marsh fritillary Euphydryas aurinia in western Bohemia (Czech Republic). J Insect Conserv 254(25):585-596. https://doi.org/10.1007/ S10841-021-00325-8

Keenan K, McGinnity P, Cross TF, Crozier WW, Prodöhl PA (2013) diveRsity : an R package for the estimation and exploration of population genetics parameters and their associated errors. Methods Ecol Evol 4:782-788. https://doi.org/10.1111/2041-210X. 12067

Kuussaari M, van Nouhuys S, Hellmann JJ, Singer MC (2004) Larval biology in checkerspots. In: Ehrlich PR, Hanski I (eds) On the wing of checkerspots: a model system for population biology. Oxford University Press, Oxford

Lacy RC (1997) Importance of genetic variation to the viability of mammalian populations. J Mammal 78:320-335. https://doi.org/ $10.2307 / 1382885$

Latch EK, Rhodes OE (2005) The effects of gene flow and population isolation on the genetic structure of reintroduced wild turkey populations: are genetic signatures of source populations retained? Conserv Genet 6:981-997. https://doi.org/10.1007/ s10592-005-9089-2

Le Gouar P, Rigal F, Boisselier-Dubayle MC, Sarrazin F, Arthur C, Choisy JP, Hatzofe O, Henriquet S, Lécuyer P, Tessier C, Susic G, Samadi S (2008) Genetic variation in a network of natural and reintroduced populations of Griffon vulture (Gyps fulvus) in Europe. Conserv Genet 9:349-359. https://doi.org/10.1007/ s10592-007-9347-6
Lenormand T (2002) Gene flow and the limits to natural selection. Trends Ecol Evol 17:183-189. https://doi.org/10.1016/S01695347(02)02497-7

Ma J, Amos CI (2012) Principal components analysis of population admixture. PLoS ONE 7:e40115. https://doi.org/10.1371/journ al.pone. 0040115

Meng XF, Shi M, Chen XX (2008) Population genetic structure of Chilo suppressalis (Walker) (Lepidoptera: Crambidae): strong subdivision in China inferred from microsatellite markers and mtDNA gene sequences. Mol Ecol 17:2880-2897. https://doi. org/10.1111/j.1365-294X.2008.03792.x

Nakahama N, Isagi Y (2018) Recent transitions in genetic diversity and structure in the endangered semi-natural grassland butterfly, Melitaea protomedia, in Japan. Insect Conserv Divers 11:330-340. https://doi.org/10.1111/icad.12280

Neve G, Barascud B, Hughes R, Aubert J, Descimon H, Lebrun P, Baguette M (1996) Dispersal, colonization power and meta population structure in the vulnerable butterfly Proclossiana eunomia (Lepidoptera: Nymphalidae). J Appl Ecol 33:14. https://doi.org/ $10.2307 / 2405011$

Nève G, Barascud B, Descimon H, Baguette M (2008) Gene flow rise with habitat fragmentation in the bog fritillary butterfly (Lepidoptera: Nymphalidae). BMC Evol Biol. https://doi.org/10.1186/ 1471-2148-8-84

Nicholls H (2005) Ancient DNA comes of age. PLoS Biol 3:e56. https://doi.org/10.1371/journal.pbio.0030056

Nichols JD, Armstrong DP (2012) Monitoring for reintroductions. In: Reintroduction biology: integrating science and management. pp. 223-255

Peng B, Kimmel M (2005) simuPOP: a forward-time population genetics simulation environment. Bioinformatics 21:3686-3687. https://doi.org/10.1093/bioinformatics/bti584

Phoenix K (2018) Butterfly reintroduction project reaches new milestone. https://www.rspb.org.uk/about-the-rspb/about-us/mediacentre/press-releases/butterfly-reintroduction-project-reachesnew-milestone. Accessed 15 July 2021

Pierzynowska K, Skowron Volponi M, Węgrzyn G (2019) Multiple factors correlating with wing malformations in the population of Parnassius apollo (Lepidoptera: Papilionidae) restituted from a low number of individuals: a mini review. Insect Sci 26:380-387

Porter K (1981) The population dynamics of small colonies of the butterfly Euphydras. University of Oxford, Oxford, UK

Porter K, Ellis S (2011) Securing viable metapopulations of the Marsh Fritillary butterfly, Euphydryas aurinia, (Lepidoptera: Nymphalidae) in Northern England. J Insect Conserv 15:111-119. https:// doi.org/10.1007/s10841-010-9328-9

R Core Team (2021) R: a language and environment for statistical computing. https://www.r-project.org/.

Ralls K, Ballou JD, Dudash MR, Eldridge MDB, Fenster CB, Lacy RC, Sunnucks P, Frankham R (2018) Call for a paradigm shift in the genetic management of fragmented populations. Conserv Lett 11:e12412. https://doi.org/10.1111/conl.12412

Richards JD, Short J (2003) Reintroduction and establishment of the western barred bandicoot Perameles bougainville (Marsupialia: Peramelidae) at Shark Bay, Western Australia. Biol Conserv 109:181-195. https://doi.org/10.1016/S0006-3207(02)00140-4

Ridding LE, Redhead JW, Pywell RF (2015) Fate of semi-natural grassland in England between 1960 and 2013: a test of national conservation policy. Glob Ecol Conserv 4:516-525. https://doi. org/10.1016/j.gecco.2015.10.004

Robert A, Colas B, Guigon I, Kerbiriou C, Mihoub JB, Saint-Jalme M, Sarrazin F (2015) Defining reintroduction success using IUCN criteria for threatened species: a demographic assessment. Anim Conserv 18:397-406. https://doi.org/10.1111/acv.12188

Ryman N, Palm S (2006) POWSIM: a computer program for assessing statistical power when testing for genetic differentiation. Mol 
Ecol Notes 6:600-602. https://doi.org/10.1111/j.1471-8286.2006. 01378.x

Sanz V, Grajal A (2010) Successful reintroduction of captive-raised yellow-shouldered amazon parrots on Margarita Island, Venezuela. Conserv Biol 12:430-441. https://doi.org/10.1111/j.15231739.1998.96261.x

Sarrazin F, Bagnolinp C, Pinna JL, Danchin E (2008) Breeding biology during establishment of a reintroduced Griffon Vulture Gyps fulvus population. Ibis (london 1859) 138:315-325. https://doi. org/10.1111/j.1474-919x.1996.tb04344.x

Schtickzelle N, Choutt J, Goffart P, Fichefet V, Baguette M (2005) Meta population dynamics and conservation of the Marsh Fritillary butterfly: population viability analysis and management options for a critically endangered species in Western Europe. Biol Conserv 126:569-581. https://doi.org/10.1016/j.biocon.2005. 06.030

Schultz CB, Russell C, Wynn L (2008) Restoration, reintroduction, and captive propagation for at-risk butterflies: a review of British and American conservation efforts. Isr J Ecol Evol 54:41-61. https:// doi.org/10.1560/IJEE.54.1.41

Seddon PJ, Armstrong DP, Maloney RF (2007) Developing the science of reintroduction biology. Conserv Biol 21:303-312. https://doi. org/10.1111/j.1523-1739.2006.00627.x

Seddon PJ, Strauss M, Innes J (2012) Animal translocations: what are they and why do we do them? In: Ewen JG, Armstrong DP, Parker KA, Seddon PJ (eds) Reintroducion biology integrating science and management. John Wiley and Sons, Ltd, Chichester, UK, pp $1-32$

Sigaard P, Pertoldi C, Madsen AB, Søgaard B, Loeschcke V (2008) Patterns of genetic variation in isolated Danish populations of the endangered butterfly Euphydryas aurinia. Biol J Linn Soc 95:677-687. https://doi.org/10.1111/j.1095-8312.2008.01078.x

Sinama M, Dubut V, Costedoat C, Gilles A, Junker M, Malausa T, Martin JF, Nève G, Pech N, Schmitt T, Zimmermann M, Meglécz E (2011) Challenges of microsatellite development in Lepidoptera: Euphydryas aurinia (Nymphalidae) as a case study. Eur J Entomol 108:261-266. https://doi.org/10.14411/eje.2011.035

Smee M (2011) Population ecology and genetics of the Marsh Fritillary Butterfly. PhD thesis. University of Exeter

Smee MR, Pauchet Y, Wilkinson P, Wee B, Singer MC, Ffrench-Constant RH, Hodgson DJ, Mikheyev AS (2013) Microsatellites for the Marsh Fritillary butterfly: de novo transcriptome sequencing, and a comparison with amplified fragment length polymorphism (AFLP) markers. PLoS ONE 8:e54721. https://doi.org/10.1371/ journal.pone. 0054721

Soorae PS (2018) Global reintroduction perspectives: 2018. Case studies from around the globe. IUCN/SSC Re-introduction Specialist Group and Abu Dhabi, EAU: Enviroment Agency-Abu Dhabi, Gland, Switzerland

Spalton JA, Lawrence MW, Brend SA (1999) Arabian oryx reintroduction in Oman: successes and setbacks. Oryx 33:168-175. https:// doi.org/10.1046/j.1365-3008.1999.00062.x

Thomas JA, Elmes GW, Wardlaw JC, Woyciechowski M (1989) Host specificity among Maculinea butterflies in Myrmica ant nests. Oecologia 79:452-457. https://doi.org/10.1007/BF00378660

Thomas JA, Simcox DJ, Clarke RT (2009) Successful conservation of a threatened maculinea butterfly. Science 80(325):80-83. https:// doi.org/10.1126/science.1175726

van Swaay C, Wynhoff I, Verovnik R, Wiemers M, López Munguira M, Maes D, Sasic M, Verstrael T, Warren M, Settele J (2010) Euphydryas aurinia. The IUCN Red List of Threatened Species. https://www.iucnredlist.org/species/174182/7024283. Accessed 29 March 2019
Veale AJ, Russello MA (2016) Sockeye salmon repatriation leads to population re-establishment and rapid introgression with native kokanee. Evol Appl 9:1301-1311. https://doi.org/10.1111/eva. 12430

Wakamiya SM, Roy CL (2009) Use of monitoring data and population viability analysis to inform reintroduction decisions: peregrine falcons in the Midwestern United States. Biol Conserv 142:17671776. https://doi.org/10.1016/j.biocon.2009.03.015

Wandeler P, Hoeck PE, Keller LF (2007) Back to the future: museum specimens in population genetics. Trends Ecol Evol 22:634-642. https://doi.org/10.1016/j.tree.2007.08.017

Watts PC, Thompson DJ, Allen K, Kemp SJ (2007) How useful is DNA extracted from the legs of archived insects for microsatellite-based population genetic analyses? J Insect Conserv 11:195-198. https:// doi.org/10.1007/s10841-006-9024-y

Wauters L, Casale P, Fornasari L (1997) Post-release behaviour, home range establishment and settlement success of reintroduced red squirrels. Ital J Zool 64:169-175. https://doi.org/10.1080/11250 009709356191

Weir BS, Cockerham CC (1984) Estimating F-statistics for the analysis of population structure. Evolution (new York) 38:1358. https:// doi.org/10.2307/2408641

West R, Read JL, Ward MJ, Foster WK, Taggart DA (2017) Monitoring for adaptive management in a trial reintroduction of the blackfooted rock-wallaby Petrogale lateralis. Oryx 51:554-563. https:// doi.org/10.1017/S0030605315001490

Whitlock MC (2010) Fixation of New Alleles and the Extinction of Small Populations : Drift Load, Beneficial Alleles, and Sexual Selection Published by : Society for the Study of Evolution Stable URL : http://www.jstor.org/stable/2640531 Fixation of New Alleles And The Ext. Evolution (N Y) 54:1855-1861

Wickham H (2009) ggplot2: elegant graphics for data analysis. Springer-Verlag, New York

Willi Y, Van Buskirk J, Schmid B, Fischer M (2007) Genetic isolation of fragmented populations is exacerbated by drift and selection. $\mathbf{J}$ Evol Biol 20:534-542. https://doi.org/10.1111/j.1420-9101.2006. 01263.x

Wisely SM, Santymire RM, Livieri TM, Mueting SA, Howard J (2008) Genotypic and phenotypic consequences of reintroduction history in the black-footed ferret (Mustela nigripes). Conserv Genet 9:389-399. https://doi.org/10.1007/s10592-007-9351-x

Wynhoff I (2001) At Home on foreign meadows: the reintroduction of two Maculinea butterfly species. Wageningen University, Wageningnen

Zimmermann K, Blazkova P, Cizek O, Fric Z, Hula V, Kepka P, Novotny D, Slamova I, Konvicka M (2011a) Demography of adults of the Marsh Fritillary butterfly Euphydryas aurinia (Lepidoptera: Nymphalidae) in the Czech Republic: patterns across sites and seasons. Eur J Entomol 108:243-254. https://doi.org/10.14411/ eje. 2011.033

Zimmermann K, Fric Z, Jiskra P, Kopeckova M, Vlasanek P, Zapletal M, Konvicka M (2011b) Mark-recapture on large spatial scale reveals long distance dispersal in the Marsh Fritillary, Euphydryas aurinia. Ecol Entomol 36:499-510. https://doi.org/10.1111/j. 1365-2311.2011.01293.x

Publisher's Note Springer Nature remains neutral with regard to jurisdictional claims in published maps and institutional affiliations. 